Volume 1, Number 1, 2015

\title{
The Energy Efficiency of the Solar Heating System with Combined Solar Collector
}

\author{
Stepan Shapoval* \\ Lviv Polytechnic National University, 12, Bandera Str., Lviv, 79013, Ukraine
}

Received: April 10, 2015. Revised: May 12, 2015. Accepted: June 22, 2015.

(C) 2015 The Authors. Published by Lviv Polytechnic National University.

\begin{abstract}
This article analyzes the influence of transparent coating on the efficiency of the combined solar collector. The prospects of solar heating systems' usage, their main problems and their solutions are described. Heat of roofing material of the building was shown to be effectively used. The task is to increase the efficiency of the combined solar collector. The results of researches of the amount of solar radiation on the combined solar collector in the gravitational system of solar heating are described. The corrugated heat sink was shown to improve the efficiency of solar collector. The importance of the protection of solar collectors by the transparent coating was described. The matrix planning of three-factor experiment with interaction of factors was composed. The analytical and graphical dependences of the efficiency of the combined solar collector with a transparent coating and without it on the angles of incidence of the heat flux and its intensity were described. The changes in the effectiveness of the combined solar collector with transparent coating were shown.
\end{abstract}

Keywords: combined solar collector; transparent coating; the coefficient of efficiency; the heat flux.

\section{The statement of the problem}

Industrial and economic sectors of Ukraine tend to resource-saving technologies, and the rates of adoption of new environmentally friendly methods for producing energy are insignificant, therefore a topical issue of modern times is the introduction of alternative energy sources. Such energy sources include wind, tides, heat of the earth's interior, oceans energy and the solar energy. The use of the latter is the most environmentally friendly and promising one. As known, the potential of solar energy is huge. The usage of about $2 \%$ of the amount of energy of the Sun could provide all the needs of today's global energy industry. One of the effective and widespread in the world energy production method is the conversion of solar radiation into the heat. Nowadays, the burning issue is the reduction in the cost of solar collectors, their design simplification and reduction in the payback period for solar heat systems. Therefore, it was proposed to use the combined solar collector, a feature of which is that its heat sink is made of roofing material of the building. It is important to explore the effectiveness of a combined solar collector in the presence and absence of a transparent coating.

\section{Analysis of recent researches and publications}

Nowadays, there is a significant energy deficit in almost all areas of the economy. The state of implementation of solar heating systems in housing and communal services requires significant improvements $[1,2,5]$. The energy efficient walling in the form of roofs and external walls of buildings (residential, public, administrative, etc) and also as elements of surfaces of industrial facilities (freezing, cooling and drying chambers, etc) have been developed [3, 4]. Such constructions allow utilizing the energy of solar radiation, heat outdoor air and exhaust air for hot water needs, air conditioning and industrial heating, as well as provide an opportunity to implement the functions of the excess heat discharge and heat storage management $[3,6]$. The wall-mounted solar collectors, which simultaneously perform the 
function of protecting structures are widely used [4, 7-9]. However, these systems have several disadvantages, among which are: their relatively high cost, a large dependence of the heat produced from the time of day, etc.

\section{The main material}

The aim of this work is to study the combined solar collector with the tube circuit arranged at heat sink in gravitational heating in the presence and absence of a transparent coating.

Experimental studies were carried out on the installation which consisted of a combined solar collector, watertank, the radiation source and measuring instruments. Scheme of the experimental unit is depicted in Fig. 1.

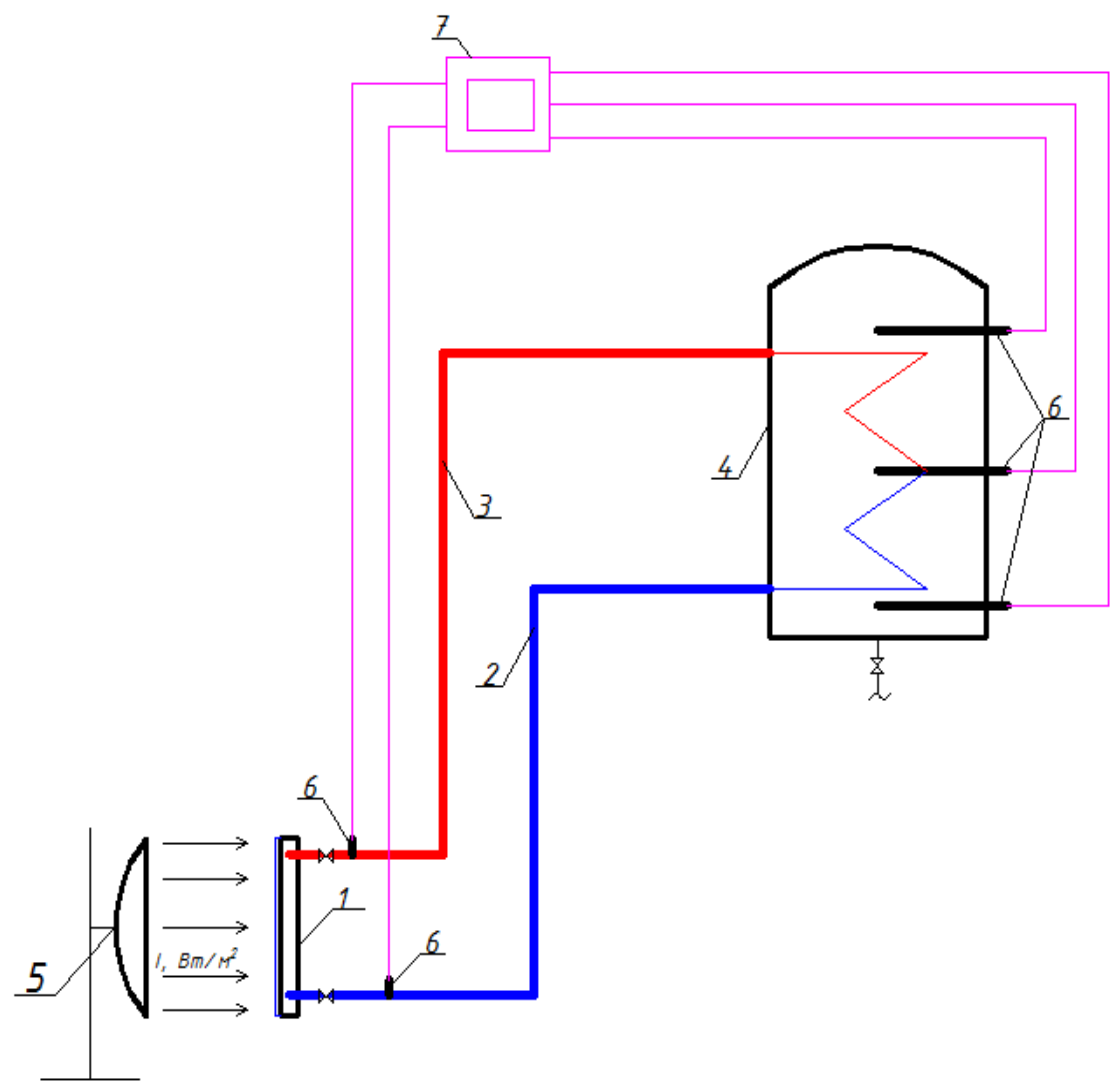

Fig. 1. Scheme of the experimental unit: 1 - combined solar collector; 2 - return pipe; 3 - feeding pipe; 4 - water tank; 5 - the source of radiation; 6 - resistance thermometers; 7 - display

The upper corrugated cover is fastened to the rafters, for example, by brackets. Solar radiation hits the absorber of solar energy. Then it is heated. Due to the temperature difference and difference in the density of the coolant in the area of the inlet and outlet ports, a circulation of the coolant is generated. The heated coolant is fed into the water tank of hot water through the feeding pipe. The water is supplied, if necessary, to the consumer. Chilled coolant returns to solar roofing in the return line, and is heated. The air is discharged through the air-release valve. The insulating layer provides for the reduction in the heat loss.

During the experiment, the following were measured: the intensity of the flow of energy; the temperature of the coolant at the entrance to solar roofing; the temperature of the coolant at the outlet of solar roofing; the temperature of the coolant in the water tank.

For the experiment, the following parameters were chosen as factors: the azimuthal angle of solar roofing, angle of inclination of solar roofing and intensity of the heat flux. The parameter levels and intervals of variation are shown in Table 1.

A three-factor experiment planning matrix considering interaction of the parameters was prepared, Table 2 . The coefficient of efficiency of solar roofing without transparent cover $K_{\text {ef } 1}$, and the coefficient of efficiency of solar roofing with a transparent coating $K_{e f 2}$ were selected as the optimization parameter. It shows how the change in the angle of incidence of the rays effects on the efficiency of a solar system. 
Table 1. The parameter levels and intervals of variation

\begin{tabular}{|c|c|c|c|c|c|}
\hline \multirow{2}{*}{ Parameter } & \multirow{2}{*}{ Code } & \multicolumn{2}{|c|}{ The levels of the parameters } & \multirow{2}{*}{$\begin{array}{c}\text { The range of } \\
\text { variation }\end{array}$} \\
\cline { 3 - 5 } & & -1 & 0 & +1 & 60 \\
\hline The azimuthal angle of solar roofing $\alpha,{ }^{\mathbf{0}}$ & $x_{1}$ & 30 & 60 & 90 & 60 \\
\hline Angle of inclination of solar roofing $\beta,^{\circ}$ & $x_{2}$ & 30 & 60 & 90 & 600 \\
\hline Intensity of heat flux $I_{6}, \mathrm{~W} / \mathrm{m} 2$ & $x_{3}$ & 300 & 600 & 900 & 600 \\
\hline
\end{tabular}

Table 2. The matrix of experiment planning

\begin{tabular}{|c|c|c|c|c|c|c|c|c|c|c|}
\hline No. & $x_{0}$ & $x_{1}$ & $x_{2}$ & $x_{3}$ & $x_{1} x_{2}$ & $x_{1} x_{3}$ & $x_{2} x_{3}$ & $x_{1} x_{2} x_{3}$ & $K_{e f 1}$ & $K_{e f 2}$ \\
\hline 1 & + & - & - & - & + & + & + & - & 0.20 & 0.58 \\
\hline 2 & + & 0 & - & - & 0 & 0 & + & 0 & 0.27 & 0.64 \\
\hline 3 & + & + & - & - & - & - & + & + & 0.33 & 0.68 \\
\hline 4 & + & - & 0 & - & 0 & + & 0 & 0 & 0.33 & 0.68 \\
\hline 5 & + & 0 & 0 & - & 0 & 0 & 0 & 0 & 0.40 & 0.72 \\
\hline 6 & + & + & 0 & - & 0 & - & 0 & 0 & 0.47 & 0.75 \\
\hline 7 & + & - & + & - & - & + & - & + & 0.47 & 0.75 \\
\hline 8 & + & 0 & + & - & 0 & 0 & - & 0 & 0.53 & 0.80 \\
\hline 9 & + & + & + & - & + & - & - & - & 0.60 & 0.83 \\
\hline 10 & + & - & - & 0 & + & 0 & 0 & 0 & 0.27 & 0.68 \\
\hline 11 & + & 0 & - & 0 & 0 & 0 & 0 & 0 & 0.33 & 0.72 \\
\hline 12 & + & + & - & 0 & - & 0 & 0 & 0 & 0.40 & 0.75 \\
\hline 13 & + & - & 0 & 0 & 0 & 0 & 0 & 0 & 0.40 & 0.75 \\
\hline 14 & + & 0 & 0 & 0 & 0 & 0 & 0 & 0 & 0.53 & 0.80 \\
\hline 15 & + & + & 0 & 0 & 0 & 0 & 0 & 0 & 0.60 & 0.83 \\
\hline 16 & + & - & + & 0 & - & 0 & 0 & 0 & 0.60 & 0.83 \\
\hline 17 & + & 0 & + & 0 & 0 & 0 & 0 & 0 & 0.67 & 0.88 \\
\hline 18 & + & + & + & 0 & + & 0 & 0 & 0 & 0.73 & 0.92 \\
\hline 19 & + & - & - & + & + & - & - & + & 0.33 & 0.75 \\
\hline 20 & + & 0 & - & + & 0 & 0 & - & 0 & 0.40 & 0.80 \\
\hline 21 & + & + & - & + & - & + & - & - & 0.47 & 0.83 \\
\hline 22 & + & - & 0 & + & 0 & - & 0 & 0 & 0.47 & 0.83 \\
\hline 23 & + & 0 & 0 & + & 0 & 0 & 0 & 0 & 0.60 & 0.88 \\
\hline 24 & + & + & 0 & + & 0 & + & 0 & 0 & 0.73 & 0.92 \\
\hline 25 & + & - & + & + & - & - & + & - & 0.73 & 0.92 \\
\hline 26 & + & 0 & + & + & 0 & 0 & + & 0 & 0.80 & 0.97 \\
\hline 27 & + & + & + & + & + & + & + & + & 1.00 & 1.00 \\
\hline
\end{tabular}

The coefficient of efficiency of solar roofing $\mathrm{K}_{e f}$ is determined by the formula:

$$
K_{e f}=\frac{y_{i}}{\mathrm{y}_{\mathrm{cT}}}
$$

where $y_{c m}$ - thermal energy received by the solar system at angles of incidence of the rays $\alpha=90^{\circ}$ and $\beta=90^{\circ}$ and the intensity of the heat flux $\mathrm{S}=900 \mathrm{~W} / \mathrm{m}^{2} ; y_{i}$ - thermal energy obtained by the solar system for other angles of incidence of the rays.

Based on the experimental results, dependence nomograms of the coefficient of efficiency of solar roofing without transparent cover $K_{e f 1}$, and the coefficient of efficiency of solar roofing with a transparent coating $K_{e f 2}$ on the azimuthal angle of solar roofing $\alpha$, angle of inclination of solar roofing $\beta$ and intensity of heat flux $I_{b}$ (Fig. 2, 3) were constructed.

After analyzing the experimental results depicted in Fig. 2, it can be concluded that the effectiveness of solar roofing without transparent cover in a gravity heating system by changing the angles of incidence $\alpha$ and $\beta$ from $90^{\circ}$ to $30^{\circ}$ is reduced by $67 \%$. 
As a result of experimental data processing, regression equation was obtained:

$$
K_{e f 1}=0.80+0.027 x_{1}+0.0546 x_{2}+0.054 x_{3}+0.001 x_{2} x_{3}+0.001 x_{1} x_{2} x_{3}
$$

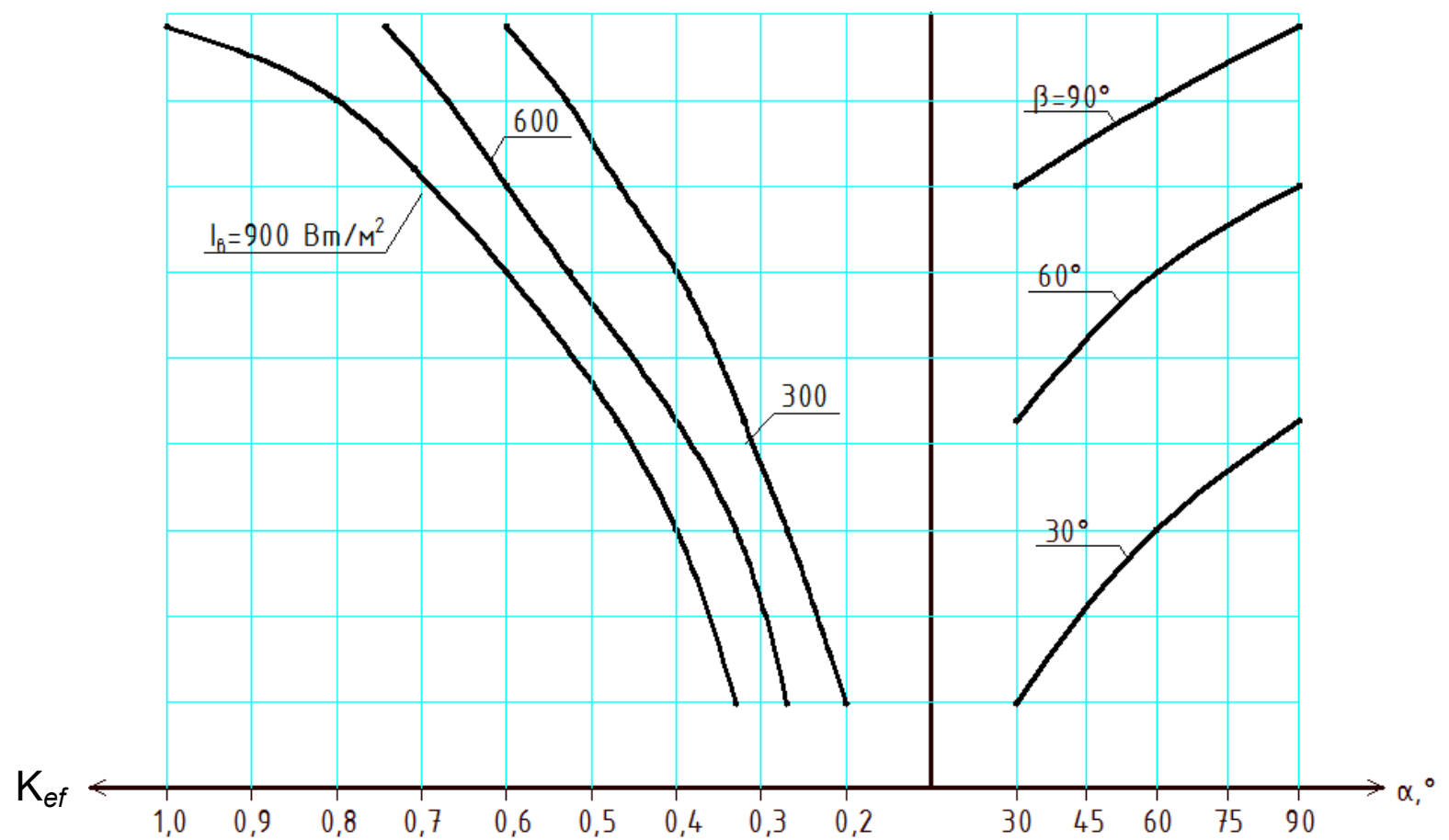

Fig. 2. The dependence nomogram of the coefficient of efficiency of solar roofing without transparent cover $K_{\text {ef } I}$ on the angles of incidence of the heat flux $\alpha$ and $\beta$ and intensity of heat flux $I_{6}$.

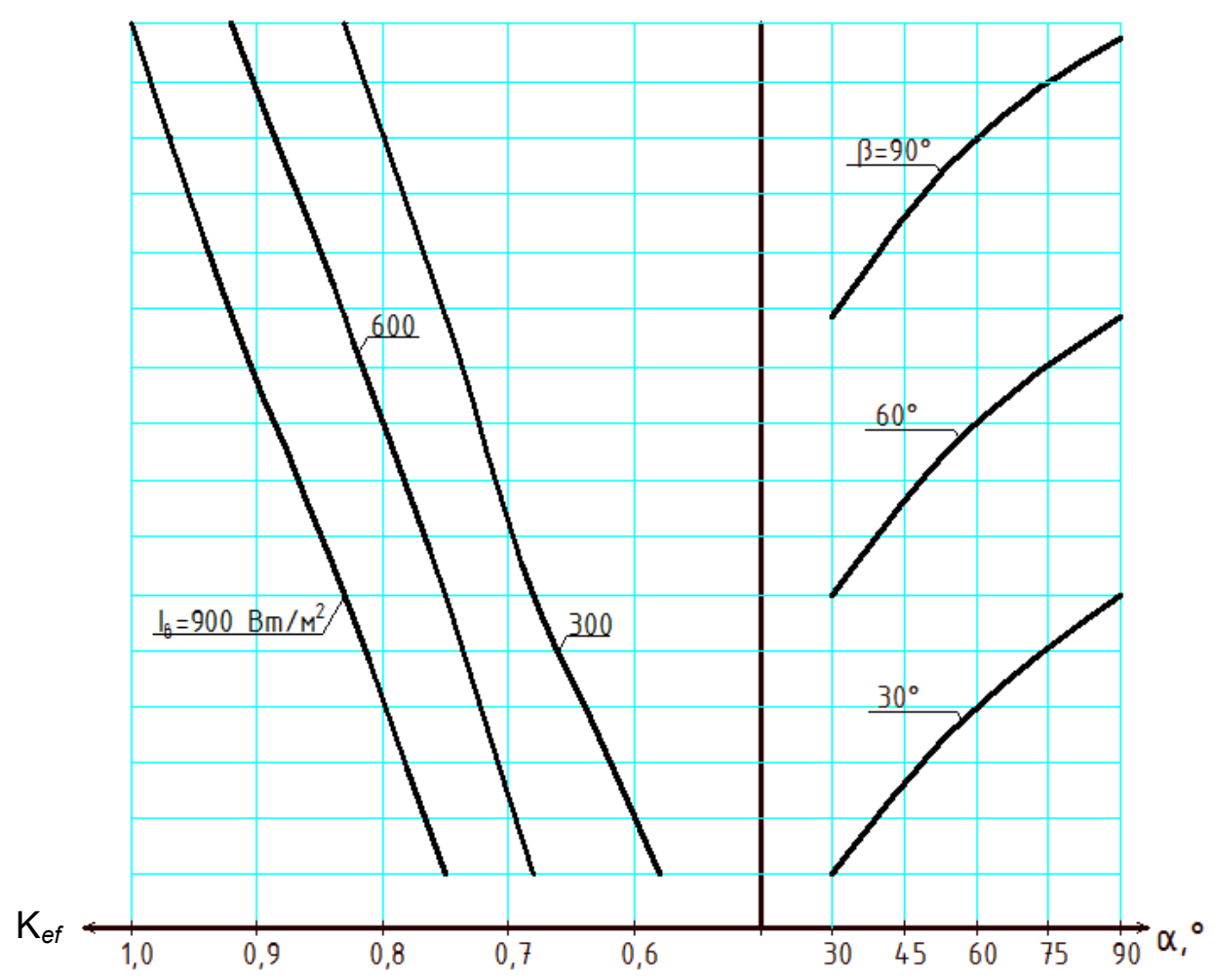

Fig. 3. The dependence nomogram of the coefficient of efficiency of solar roofing with transparent cover $K_{\text {ef } 1}$ on the angles of incidence of the heat flux $\alpha$ and $\beta$ and intensity of heat flux $I_{6}$. 
Based on the analysis of the regression coefficients, we can state that a factor $x_{2}$ (the angle of inclination of solar roofing $\beta,{ }^{\circ}$ ) and $x_{3}$ (the intensity of the heat flux $I_{b}, \mathrm{~W} / \mathrm{m}^{2}$ ) has significant impact on the behavior of the response function, while the factor $x_{1}$ (the azimuthal angle of solar roofing $\alpha,{ }^{\circ}$ ) does not have such strong influence. The numerical increase in all factors leads to higher efficiency of solar roofing. The combined effect of the factors is insignificant.

After analyzing the experimental results depicted in Fig. 2, it can be concluded that the effectiveness of solar roofing without transparent cover in a gravity heating system by changing the angles of incidence $\alpha$ and $\beta$ from $90^{\circ}$ to $30^{\circ}$ is reduced by $32 \%$, while in conventional flat solar collectors it is reduced by $60 \%$. Change in the angles of incidence of solar radiation leads to a minor drop in efficiency of solar roofing.

Based on the nomogram, we have obtained empirical dependence of efficiency of solar roofing with transparent cover $K_{\text {ef } I}$ on the angles of incidence of the heat flux $\alpha$ and $\beta$ and intensity of heat flux $I_{6}$ :

$$
\begin{aligned}
& K_{e f 2}=\left(0.1915+0.0004 \cdot x_{3}\right)+\left(0.002+2.1667 \cdot 10^{-6} \cdot x_{3}\right) \cdot x_{1}+\left(0.0129-1.5 \cdot 10^{-5} \cdot x_{3}\right) \cdot x_{2}+ \\
& +\left(3.0865 \cdot 10^{-6}-4.6297 \cdot 10^{-8} \cdot x_{3}\right) \cdot x_{1}^{2}+\left(4.6295 \cdot 10^{-6}+3.7037 \cdot 10^{-8} \cdot x_{3}\right) \cdot x_{1} \cdot x_{2}+ \\
& +\left(9.0391 \cdot 10^{-5}+1.1222 \cdot 10^{-7} \cdot x_{3}\right) \cdot x_{2}^{2} .
\end{aligned}
$$

\title{
4. Conclusion
}

The use of solar roofing in the solar heating systems allows us to significantly reduce the cost of solar systems. An important factor that affects the efficiency of solar roofing is a transparent coating. The researches show that the coefficient of efficiency of solar roofing with transparent coating is $35 \%$ higher than the coefficient of efficiency of solar roofing without it.

\section{References}

[1] Mysak Y. S. Solar Energy: Theory and Practice : monograph / Y. S. Mysak, O. T. Vozniak, A. S. Datsko, S. P. Shapoval. - Lviv : Publishing house of Lviv Polytechnic, 2014. - 340 p. (in Ukrainian)

[2] Shapoval S. P. The Efficiency of the Heating System based on Solar Collector when the Angle of the inflow Heat Flux is changing / S. P. Shapoval, A. T. Vozniak, O. S. Datsko // Bulletin of Lviv Polytechnic National University "The theory and practice of construction".Lviv : Publishing house of Lviv Polytechnic, 2009. - № 655. - S. 299-302. (in Ukrainian)

[3] Strashko V. V. Methods of Experimental Determination of the Average Integral Temperature of the Heat-absorbing Surface of Solar Profile TIPS / V. V. Strashko // EcoTechnologies and resources. - 2005. - No. 6 - P. 68-71. (in Ukrainian)

[4] Kozlov J. M. Optimization of the Location of Solar Collectors in Solar Systems / J. M. Kozlov, M. P. Suhyi, C. M. Suhyi // East European journal of advanced technologies. - 2010. - № 2/10 (44). - P. 58-64.

[5] Thermal Performance of a Solar Heat Storage Accumulator Used For Greenhouses Conditioning / [Mejdi Hazami, Sami Kooli, Meriam Lazaar, Abdelhamid Farhat, Ali Belghith] // American Journal of Environmental Sciences. - 2005. - № 1 (4). - P. 270-277.

[6] Dorozhovets M. M. Processing of Measurement Results : textbook / M. M. Dorozhovets. - Lviv : Publishing house of Lviv Polytechnic, 2007. - 624 p. (in Ukrainian)

[7] Magomedov M. A. Non-traditional Renewable Energy Sources / N. A. Magomedov. - Makhachkala : Jupiter, 1996. -245 p.

[8] Paranchych S. U. The Use of Solar Energy : textbook / S. U. Paranchych. - Chernivtsi : Ruta, 2002. - 47 p. (in Ukrainian)

[9] Lorenz P. The Economics of Solar Power / P. Lorenz, D. Pinner, T. Seitz. - The McKinsey Quarterly, June 2008. - P. 19.

\section{Енергетична ефективність системи сонячного теплопостачання із комбінованим геліоколектором}

\author{
Степан Шаповал
}

Націіональний університет “Львівська політехніка”, вул. С. Бандери, 12, м. Львів, 79013, Україна

\section{Анотація}

Проаналізовано вплив прозорого покриття на ефективність комбінованого геліоколектора. Описано перспективи використання систем сонячного теплопостачання, основні їхні проблеми та способи їх 
вирішення. Показано, що можна ефективно використовувати тепло покрівельного матеріалу будівлі. Поставлено завдання підвищити ефективність комбінованого геліоколектора. Описано результати досліджень надходження сонячного випромінювання на комбінований геліоколектор у гравітаційній системі сонячного теплопостачання. Показано, що гофрований теплопоглинач дає змогу підвищити ефективність геліоколектора. Описано важливість захисту геліоколекторів прозорим покриттям. Складено матрицю планування трифакторного експерименту із урахуванням взаємодії факторів. Відображено аналітичні та графічні залежності ефективності комбінованого геліоколектора 3 прозорим покриттям та без нього від кутів падіння теплового потоку та його інтенсивності. Показано, наскільки змінюється ефективність комбінованого геліоколектора під час покриття його прозорим захищенням.

Ключові слова: комбінований геліоколектор; прозоре покриття; коефіцієнт ефективності; тепловий потік. 